\title{
Discussion on the Revision Direction of China's Civil Aviation Carrier Liability System
}

\author{
Xianhua Tian \\ Nanchang Institute of Technology, Nanchang 330044, China. \\ tianxianhua2004@163.com
}

Keywords: Air transport, civil aviation law of china, the Montreal convention in 1999, carrier's liability system, the law revision.

\begin{abstract}
The current Civil Aviation of the People's Republic of China has existed for 20 years so far since it was issued, in which the legal provisions on the personal damage compensation for civil aviation passengers do not adapt to the social development. Therefore, it is expected to be improved. In this paper, the deficiencies of the personal damage compensation system of China's civil aviation companies for passengers are analyzed, according to the actual conditions of China and the legislative experience of the Montreal Convention 1999, and then suggestions for the revision of the liability system of China's civil aviation carrier.
\end{abstract}

\section{Introduction}

The data of the Aviation Safety network in 2014 showed that the overall quantity of the global Aviation Safety accidents declined, but the passenger death toll rose sharply. Especially after 3.8Malaysia flight disappearances occurred, the claim for compensation is a wake-up call for China.

\section{The Deficiencies of China's Current Civil Aviation Law Carrier Liability System}

The development of China's aviation industry has been greatly promoted by the rapid economic development, and the Civil Aviation Act made in 1995 is too simple and rough in many aspects. The legal provisions of China on the personal damage compensation for civil aviation passengers appear more inappropriate, especially when innovations were made to the Montreal Convention 1999 in terms of liability for damage, liability limits adjustment, the fifth jurisdiction, and advance payment. Today, the global flight codes are shared, but the above innovative practice has not been used by China's civil aviation companies as reference so that the personal damage compensation system appears to divorce from the economic development and becomes inapplicable in judicial practice. The deficiencies of the personal damage compensation system are summarized as below.

\subsection{The Limitation of Liability is Inelastic.}

Stipulation on Domestic Air Transport Carrier's Limitation of Liability for Damage (No.160) (referred to as Stipulation below) was issued by China's General Administration of Civil Aviation and implemented from March 28, 2006. In the Stipulation, the limitation of liability is 400,000 RMB for each passenger, significantly higher than 70,000 RMB in the Temporary Provisions on the Personal Damage Compensation of Domestic Civil Aviation Companies for Each Passenger (referred to as Temporary Provisions) [1].

Since China accessed to the Montreal Convention 1999 in 2005, China's civil aviation companies need to coordinate the international and domestic personal damage compensation systems for passengers. Previously, in both international law and domestic law, the maximum compensation limit from domestic transportation and international transportation was stipulated on the personal damage compensation for passengers, but the limits were different- the limit of the international air transport was higher. In article 4 of the opinions manuscript of the Stipulation, the provision in the Montreal Convention 1999 is used for reference-a double-gradient compensation liability system is applied [2]. However, the legislative innovation practice in the Montreal Convention 1999 is not taken into consideration to apply the limit of compensation. 


\subsection{A Lack of Regular Review Mechanism in the Compensation System.}

The adjustment to the limitation of liability in article 4 of the Stipulation is formulated by the competent civil aviation authority under the state council, and then published and implemented after getting an approval from the state council. In this article, the adjustment to the limitation of liability is irregular and seems too simple and rough; factors and quantitative standards affecting the adjustment are not provided. In article 24 of the Montreal Convention 1999, the establishment of a regular review mechanism for the limitation of liability is provided.

\subsection{Unauthorized Legislation for the Limitation of Liability of Civil Aviation Companies.}

Article 124 in the Civil Aviation Act of the People's Republic of China actually goes against the legislative law. Article 8 of China's legislative law provides that a law is necessarily made concerning about the basic civil system. Civil compensation is not in the legislative scope of administrative rules and regulations. The limit of the personal damage compensation for each aviation passenger should be prescribed by law, but not be in the scope of the legislative scope of the state council or the civil aviation administration.

\subsection{Absent Advance Payment System.}

An absent advance payment system does not match with China's status (i.e. a responsible superpower), and also is unfavorable for China to keep pace with the international civil aviation market. From the angle of legislation, the civil aviation act shall balance the legitimate interests of civil aviation carrier, consumers, and all relevant parties. Considering the development of aviation technology and the airlines solid economic strength, protecting the interests of civil aviation consumers has become an urgent need. After civil aviation accident occurred, the carrier shall timely pay for the natural person who has the right to claim for compensation, thus presenting the humanities concern for consumers and also the legislative direction of law to protect the vulnerable groups [3].

\subsection{Absent Fifth Jurisdiction.}

As China accessed to the Montreal Convention 1999, the current civil aviation act with the absent establishment of the fifth jurisdiction seems to be inappropriate and unfair. With the fifth jurisdiction as a new right of jurisdiction, the protection of passengers is intensified by the passengers' home court, and a new way is available for passengers to appeal. The fifth jurisdiction refers to the jurisdiction of the passengers' home court. If the passengers' residence is in his state of nationality, personal jurisdiction is similar to an extension of public international law to private international law, so that the jurisdiction of passengers' home court increases and the court shall have jurisdiction over the cases. Thus, the protection of the rights and interests of passengers is enlarged indeed.

\section{A Bad Reflection of Justice in China's Civil Aviation Carrier Liability System}

After civil aviation accidents occurred, the civil aviation company shall timely provide convenience for the person, who has the right to claim for compensation. However, the flaws of the law giving rise to great judicial inconvenience in compensation have been the facts that are not disputed, specifically as follows.

\subsection{Differences between the Domestic Flights and International Flights in the Personal Damage Compensation Standards for Passengers.}

Two plane crashes occurred continuously in China in 2002, which were 4•15Fusan Plane Crash and 5-7Dalian Plane Crash. The compensation standards applied to the two plane crashes were highly controversial. In justice, the personal damage compensation for passenger was ultimately determined by the flight's nature (i.e. international or domestic flight). How was the flight's nature determined? It depended on the origin, destination, and pauses. 4•15Fusan Plane Crash was international flight, and therefore, the maximum limit $\$ 75000$ (i.e. 600,000RMB) stipulated in the Montreal Convention 1966 was applied. 5•7Dalian Plane Crash was domestic flight, and therefore, the compensation standard in the domestic law was applied [4]. 


\subsection{Personal Damage Compensation in Civil Aviation Liability Accident is Actually the Over-Quota Compensation.}

After 8•24Yichun Plane Crash occurred, the compensation standard for passengers was released by Henan Airlines co., LTD.: the compensation for each passenger was 960,000RMB totally-it was the over-quota compensation actually. A survey report showed that $8 \cdot 24$ Yichun Plane Crash was an extremely serious man-made "liability accident" - the fault of the pilots was obvious in the occurrence of the accident. According to China's Provisions on Domestic Air Transport Carrier's Limit of Liability, the limit of liability for each passenger is 400,000 RMB. In 8•24Yichun Plane Crash, the shadow of "double-gradient compensation principle" was actually adopted, reflecting the legal spirit of the double-gradient compensation principle provided in the Montreal Convention 1999. 3.3 Family Members Involved in Baotou Air Crash Went to the United States and Claim for Compensation.

The reason why family members involved in Baotou Air Crash was that the compensation paid by the civil aviation carrier for the victims was fewer. Because of the very slow domestic compensation process, the family members of some victims chose to authorize a lawyer in the United States and claim for compensation. In the case trial process, the American judge thought that the most suitable court for the jurisdiction of the case shall be the Chinese court in accordance with the "convenient jurisdiction principle".

\section{Suggestions on the Revision Direction of China's Civil Aviation Carrier Liability System}

Considering China's accession to the Montreal Convention 1999 and also according to the international principle of "abiding by agreements", the Convention's relevant provisions are necessarily incorporated into China's Civil Aviation Act. It is very necessary to fully draw lessons from the advanced legislation experience of the Montreal Convention and constantly improve China's Civil Aviation Act.

\subsection{Setting up a "Double-Gradient" Compensation Liability System.}

In order to improve the limitation of liability, the limited compensation system provided by the Warsaw Convention was abandoned by the Montreal Convention in 1999 in terms of the aviation passenger transportation liability system, and then the "double gradient" unlimited liability system was adopted. In Article 23 the Montreal Convention, the international monetary fund's "special drawing rights" (SDRs) is provided as unit; in term 1 of article 17, the maximum compensation limit in air crash is 100,000 SDRs (i.e. \$135,000) on the boundary of "double gradient" liability system.

\subsection{Setting up a Flexible Mechanism for the Limitation of Liability and a Regular Mechanism} for Regular Examination.

In the Provisions on Domestic Air Carrier's Limitation of Liability, the limitation of liability in air crash is increased to $400,000 \mathrm{RMB}$, thus solving the inappropriate problem of the old regulations and also reflecting the concern of the government on the right to life to a certain extent. The gap from the limitation of liability in international air crash is reduced. Thus, it is a legislative progress.

\subsection{Adopting an Advance Payment System.}

In accordance with Article 2 of the Montreal Convention 1999, the carrier shall not delay the advance payment in the case that the death or injury of passengers is caused by aviation accidents. The advance payment amount should meet the "immediate economic needs".

\subsection{Adding the Fifth Jurisdiction.}

Generally, the four-jurisdiction provided in the Warsaw Convention has been able to meet the needs of the international air transport controversy. In today's economic development, the fifth jurisdiction is officially confirmed by the government of all countries in accordance with the Montreal Convention for the purpose of the maximum protection of personal rights and interests of citizens, and the jurisdiction of the home's court of the plaintiff is added. 


\section{Conclusion}

With the development of the civil aviation of China and the connection with the international civil aviation transportation, the role of the law in the protection of civil aviation passengers is necessarily fully played. Appropriate reference to the Montreal Convention is very necessary. Meanwhile, the actual situation of China is necessarily considered, and a complete duplication is prohibited. However, the particularity of a country should never be blindly stressed to intentionally avoid the related compensation rules. Therefore, the inappropriate parts of the previous civil aviation are necessarily modified, and the related legal compensation system in the Montreal Convention is included into China's civil aviation law.

\section{Acknowledgements}

This paper was the periodic result of the Youth Fund Project of about the Humanities and Social Science Research in the Colleges and Universities of Jiangxi Province in 2013, "Study on the Countermeasures for the Absent Personal Damage Compensation Legal System in China's Civil Aviation Companies" (No. FX1328).

\section{References}

[1]. Han Wang, Chauhan Zhang. Self-criticism on the Advance Payment System of the Montreal Convention 1999 [J]. Journal of the Era of Law, 2011 (02): 21-24.

[2]. Nuancing Dong. China's Aviation Law: Cases and Problems in Research [M]. Beijing: Law Press, 2007:126.

[3]. The Civil Aviation Administration of the People's Republic of China. The Answers from Yahoo Yuan, president of the Department of the Policies and Regulations of Civil Aviation Administration, To Reporters' Questions with regard to the Domestic Air Transport Carrier's Limitation of Liability [R]. The Civil Aviation of China, 2006:16.

[4]. Convention for the Unification of Certain Rules for International Carriage by Air Montreal, www.jus.uio.no,1999-05-28. 